๑ Entomologica Fennica. 23 November 2001

\title{
Lepidoptera collected in the Canadian Arctic during the Tundra Northwest 99 expedition
}

\author{
Jens Rydell, Heikki Roininen, Kenelm W. Philip \& Ali Karhu
}

Rydell, J., Roininen, H., Philip, K. W. \& Karhu, A. 2001: Lepidoptera collected in the Canadian Arctic during the Tundra Northwest 99 expedition. — Entomol. Fennica 12: 131-138.

During the Swedish-Canadian icebreaker-based expedition to the Nearctic in summer 1999 (July and early August), moths and butterflies (Lepidoptera) were collected during short, helicopter-aided visits to eight sites in the Canadian archipelago, three sites on the Canadian mainland near the arctic coast and also at Thule Air Force Base in north Greenland. Some of the visited sites (notably those on Melville Peninsula, Somerset Island and King William Island) have not previously been investigated with respect to their insect faunas. Several records thus represent species range extensions. They generally corroborate an earlier hypothesis, based on a floristic zonation scheme, which has been used as a framework for understanding the distribution of Arctic butterflies.

Jens Rydell, Zoology Department, Göteborg University, P.O. Box 463, SE-40530 Göteborg, Sweden; E-mail: jens.rydell@zool.gu.se

Heikki Roininen \& Ali Karhu, Department of Biology, University of Joensuu, P.O. Box 111, FIN-80101 Joensuu, Finland

Kenelm W. Philip, Institute of Arctic Biology, University of Alaska, P.O. Box 757000, Fairbanks, AK 99775-7000, U.S.A.

Received 1 September 2000, accepted 12 March 2001

\section{Introduction}

Moths and butterflies were collected during the first, westbound, leg of the Swedish/Canadian Tundra Northwest 99 Expedition, based on the Canadian Coast Guard ice-breaker Louis S. StLaurent, which traversed the Canadian Arctic archipelago in July and August 1999 (Fig. 1). Short (up to $36 \mathrm{~h}$ ) helicopter-aided collecting camps were established on the tundra of seven islands or peninsulas in the high arctic, as well as on two sites on the mainland. In addition a few hours were spent collecting during the return flight to Sweden, namely at Tuktuyaktuk in the McKenzie
River delta and Thule Air Force Base in north Greenland. A few specimens were also collected by expedition participants during the second, eastbound, leg.

Particularly in the central and northern parts of the Canadian Arctic, insects have been collected primarily at scientific stations. These were established for the purpose of long-term research projects, e.g. at Lake Hazen and Alexandra Fiord on Ellesmere Island (Svoboda \& Freedman 1994), at Truelove Lowland on Devon Island (Bliss 1977), at Isachsen on Ellef Ringnes Island (McAlpine 1964) and at Polar Bear Pass on Bathurst Island (Danks 1980). In contrast, most of the sites 


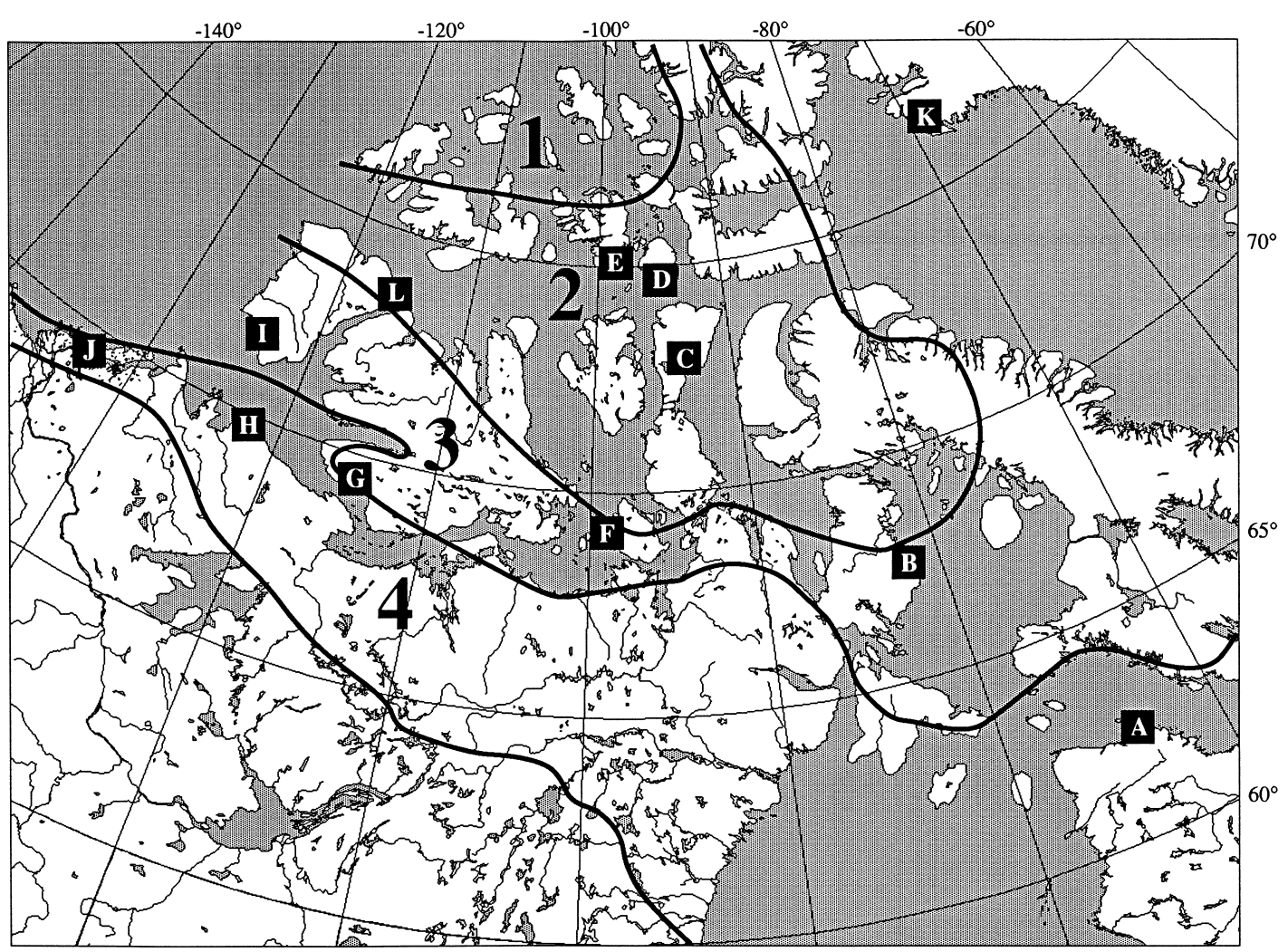

Fig. 1. Map of arctic Canada showing the locations of the collecting sites (A-L; see Table 1). The floristic zonation of Young (1971) is shown. The zones are referred to by their numbers.

that were visited during this expedition, i.e. those on the Melville Peninsula, Somerset Island and King William Island, are located far from established research stations and in places where lepidopterans have not been collected previously. Our collecting efforts thus resulted in either range extensions or the filling of gaps in the distribution maps for several species. The collected specimens have been split between the Zoology Department, Göteborg University (Sweden); the Department of Biology, University of Joensuu (Finland); and the collection of the Alaska Lepidoptera Survey in Fairbanks, Alaska (USA).

\section{Sampling sites and weather}

The collecting efforts not only extended over a large geographical area but also over more than one month in time (2 July to 10 August 1999; Fig. 1 and Table 1). The sea ice was extensive during the early part of 1999 , and the summer arrived late particularly in the western islands (King
William, Victoria and Banks Islands). Information on the location, habitat, vegetation and the weather at each site is given in Table 1.

Our collecting sites were usually located between 5 and $15 \mathrm{~km}$ from the coast. By avoiding the coastline, we attempted to minimize the risk of being covered by mist and also encounters with polar bears. On the other hand, the flight range of the helicopters limited the travel distances. However, three of the sites (D, J and K; at Resolute, Tuktuyaktuk and Thule, respectively), which were in the immediate vicinity of villages, were located at or near the coast. For more information about the climate, geology and other features of the general area, see Young (1971), Danks (1981) and Grönlund (2000).

At each landing site three camps (arbitrarily named the "yellow", "red" and "blue" camps, respectively) were established a few $\mathrm{km}$ from each other but usually within sight distance. Insects were collected at the yellow camp and in three cases (sites C, G and H; at Somerset Island, Victoria Island and Pearce Point) also at the red camp. Coordinates and habitat information (Table 1) are given for the yellow camp only. The collecting habitats were usually similar at the two camps, although the red camp was usually a few $\mathrm{kms}$ closer to the sea and at slightly lower elevation than the yellow camp. 
The flight period of Lepidoptera in the high arctic varies considerably from year to year, depending on the weather, and therefore the sampling date is not very informative in prediction of flight periods. However, butterfly phenology is presumably related to the phenology of the plants. Therefore, we recorded the flowering stage of some common tundra plants at each locality, to facilitate comparison between the sites (Table 2). Plant phenology can perhaps also be used as a phenological indicator during future collecting visits to northern Canada and elsewhere in the arctic.

\section{Results}

The Lepidoptera collected at each site are given in Table 3. The first butterflies (Boloria sp.) were observed flying in sunny weather in Iqaluit (eastern Baffin Island) 29 June, but no specimens were collected there. At the first collecting site, the northern tip of Ungava Peninsula (site A; visited 1-2 July), we encountered snowy weather, and no lepidopterans were seen. However, at the next two sites, Melville Peninsula (site B; 5-6 July) and Somerset Island (site C; 9-10 July), which were visited in warm and sunny weather, recently emerged specimens of the early flying species Boloria polaris, $B$. freija and $B$. frigga were caught on south-facing gravel slopes. $B$. polaris was particularly abundant at these sites. Later flying species, including B. chariclea, Colias nastes and Agriades glandon, had not yet emerged, but were encountered as larvae or pupae. The two sites consisted of variable tundra habitats with polygons, and with dry and mesic heaths and wetter grass and sedge dominated plant communities. Ridges and exposed hillsides were typically dry and dominated by gravel with patches of Salix

Table 1. Sites visited during the Tundra Northwest 99 Expedition, the dates of the visits and the location (latitude and longitude), altitude and distance from the coast of the "yellow camp". The zones are the floristic zones used by Young (1971). Plant diversity is the number of vascular plants recorded at the site (compiled by B. Eriksen et al., see Grönlund 2000). Temperatures were measured $1 \mathrm{~m}$ above ground level. "Weather" means the best collecting weather encountered at the site.

\begin{tabular}{|c|c|c|c|c|c|c|c|}
\hline \multicolumn{4}{|l|}{ Site } & Date & \multicolumn{2}{|l|}{ Location } & \multirow{2}{*}{$\frac{\text { Altitude }}{50-150}$} \\
\hline$A$ & \multicolumn{3}{|c|}{ Cap de Nouvelle-France, Ungava Pen. } & 1-2 July & \multicolumn{2}{|c|}{$62^{\circ} 22.0^{\prime} \mathrm{N}, 73^{\circ} 47.6^{\prime} \mathrm{W}$} & \\
\hline $\mathrm{B}$ & \multicolumn{3}{|c|}{ Cape Penhryn, Melville Peninsula } & 5-6 July & \multicolumn{2}{|c|}{$67^{\circ} 35.9^{\prime} \mathrm{N}, 81^{\circ} 43.0^{\prime} \mathrm{W}$} & $100-200$ \\
\hline C & \multicolumn{3}{|c|}{ Creswell Bay, Somerset Island } & 9-10 July & \multicolumn{2}{|c|}{$72^{\circ} 55.3^{\prime} \mathrm{N}, 93^{\circ} 27.1^{\prime} \mathrm{W}$} & $50-100$ \\
\hline $\mathrm{D}$ & \multicolumn{3}{|c|}{ Resolute Bay, Cornwallis Island } & 12 July & \multicolumn{2}{|c|}{$74^{\circ} 42.1^{\prime} \mathrm{N}, 94^{\circ} 50.0^{\prime} \mathrm{W}$} & $10-20$ \\
\hline$E$ & \multicolumn{3}{|c|}{ Bathurst Island } & 13-14 July & \multicolumn{2}{|c|}{$75^{\circ} 04.1^{\prime} \mathrm{N}, 98^{\circ} 31.0^{\prime} \mathrm{W}$} & $50-120$ \\
\hline $\mathrm{F}$ & \multicolumn{3}{|c|}{ King William Island } & 20-21 July & \multicolumn{2}{|c|}{$69^{\circ} 06.7^{\prime} \mathrm{N}, 98^{\circ} 55.2^{\prime} \mathrm{W}$} & 30 \\
\hline $\mathrm{G}$ & \multicolumn{3}{|c|}{ Wollaston Peninsula, Victoria Island } & 23-24 July & \multicolumn{2}{|c|}{$69^{\circ} 26.2^{\prime} \mathrm{N}, 114^{\circ} 43.9^{\prime} \mathrm{W}$} & $90-180$ \\
\hline $\mathrm{H}$ & \multicolumn{3}{|c|}{ Pearce Point, near Albert Bay } & 26-27 July & \multicolumn{2}{|c|}{$69^{\circ} 45.8^{\prime} \mathrm{N}, 122^{\circ} 03.3^{\prime} \mathrm{W}$} & $80-100$ \\
\hline I & \multicolumn{3}{|c|}{ Banks Island, south } & 28-29 July & \multicolumn{2}{|c|}{$71^{\circ} 42.1^{\prime} \mathrm{N}, 123^{\circ} 44.7^{\prime} \mathrm{W}$} & $100-150$ \\
\hline $\mathrm{J}$ & \multicolumn{3}{|c|}{ Tuktuyaktuk } & 31 Juy & \multicolumn{2}{|c|}{$69^{\circ} 27^{\prime} \mathrm{N}, 133^{\circ} 02^{\prime} \mathrm{W}$} & $0-5$ \\
\hline $\mathrm{K}$ & \multicolumn{3}{|c|}{ Thule Air Base, north Greenland } & 2 August & \multicolumn{2}{|c|}{$76^{\circ} 34^{\prime} \mathrm{N}, 68^{\circ} 48^{\prime} \mathrm{W}$} & $0-50$ \\
\hline $\mathrm{L}$ & \multicolumn{3}{|c|}{ Banks Island, north } & 10-11 August & \multicolumn{2}{|c|}{$73^{\circ} 37^{\prime} \mathrm{N}, 115^{\circ} 50^{\prime} \mathrm{W}$} & $100-200$ \\
\hline Site & Zone & Habitat & Moisture & Plant diversity & Maximum temp. $\left({ }^{\circ} \mathrm{C}\right)$ & Wea & \\
\hline A & 4 & Tundra & Dry-wet & 44 & +2 & snc & rong wind \\
\hline $\mathrm{B}$ & 3 & Tundra & Dry-wet & 38 & +16 & sun & \\
\hline $\mathrm{C}$ & 2 & Tundra & Dry-wet & 42 & +15 & sunr & rong wind \\
\hline $\mathrm{D}$ & 2 & Tundra & Dry & not rec. & +2 & clou & ght rain \\
\hline $\mathrm{E}$ & 2 & Tundra & Dry-mesic & 29 & +13 & sunr & rong wind \\
\hline $\mathrm{F}$ & 3 & Tundra & Dry-mesic & 44 & +12 & sunr & rong wind \\
\hline $\mathrm{G}$ & 4 & Tundra & Dry-mesic & 76 & +7 & sunı & rong wind \\
\hline $\mathrm{H}$ & 4 & Tundra & Dry-wet & 56 & +5 & fogc & \\
\hline I & 3 & Tundra & Dry-mesic & 69 & +17 & sunr & rong wind \\
\hline$J$ & 4 & Roadside & Mesic-wet & not rec. & +20 & sun & \\
\hline $\mathrm{K}$ & 3 & Tundra & Dry-mesic & not rec. & +15 & sun & \\
\hline $\mathrm{L}$ & 2 & Tundra & Dry-mesic & not rec. & +14 & sun & \\
\hline
\end{tabular}


arctica, Dryas integrifolia and moss and lichen cushions.

No butterflies were encountered at the two northernmost islands (D and E; Cornwallis and Bathurst Islands), which were visited 12 and 1314 July, respectively, but the geometrid Psychophora sabini was found at both places and the lymantriid Gynaephora groenlandica was found at Bathurst Island (Table 3). Cornwallis and Bathurst Islands can be characterized as "polar desert", with little plant cover (McAlpine 1964, Danks \& Byers 1972).

The locality at King William Island (site F; 20-21 July) consisted of an almost flat, dry limestone plateau with shallow lakes. At this site insect abundance was probably near the peak of the year when we arrived. Butterflies were abundant and we also found one individual of the arctiid Pararctia lapponica and the two lymantriids Gynaephora groenlandica and G. rossi in large numbers. The site at Wollaston Peninsula on southwestern Victoria Island (G; 23-24 July) consisted of rolling hills, and was relatively rich in plants and presumably also in insects. The weather encountered at this site was generally cool and windy, but during a few hours of sunshine we saw at least seven species of butterflies and a few moths. At the site near Pearce Point on the mainland (site H; 26-27 July), an area of eroded sandstone hills, the weather was persistently foggy and cool, and we encountered only two butterfly and two moth species.

Our visit on the southern part of Banks Island
(I; 28-29 July) probably coincided with the peak flight period for butterflies, which were abundant in sheltered ravines, where they were able to fly despite the prevailing strong wind. We observed fifteen species of butterflies at this locality. We also found several moths, including Grammia quenseli and Gynaephora groenlandica, the latter in enormous numbers (ca. $1 \mathrm{~kg}$ per ha; $\mathrm{H}$. Roininen \& J. Rydell, unpublished observations): G. rossi (one individual), a geometrid (Entephria punctipes), noctuids (four species), pterophorids (two species), a pyralid (Loxostege ephippialis) and tortricids (two species). The northern part of Banks Island (site L) was later (10-11 August) visited by participants of the second leg of the expedition, which caught three species of butterflies (Colias nastes, Boloria frigga and B. polaris).

During a few hours at Thule Air Force Base (K) in sunny weather we caught all five species of butterflies known from Greenland. We also collected G. groenlandica, two geometrids, one noctuid and one tortricid species (Table 3).

Gynaephora species were sometimes encountered in much higher numbers than the collecting record (Table 3) suggests. For example, on Somerset Island (site C), Bathurst Island (site E) and King William Island (site F), we used virgin females to attract males during an experiment (Rydell et al. 2000), but since most of the males were not collected they were not identified to species. However, we caught enough specimens to confirm that males of both species of Gynaephora

Table 2. Phenology of some common tundra plants at each of sites visited (except sites $J$ and $L$ ). 1, First leaves appearing; 2, leaves fully developed; 3 , flower buds developed; 4, flowers open; 5 , flowers wilting; 6 , fruit developed. The sites and dates are according to Table 1.

\begin{tabular}{|c|c|c|c|c|c|c|c|c|c|c|}
\hline \multirow[b]{2}{*}{ Plant species } & \multicolumn{10}{|c|}{ Site } \\
\hline & $A$ & B & C & $\mathrm{D}$ & $E$ & $\mathrm{~F}$ & G & $\mathrm{H}$ & I & $\mathrm{K}$ \\
\hline Saxifraga oppositifolia & 4 & 4 & $4-5$ & $4-5$ & $4-5$ & 6 & 6 & 6 & 6 & 6 \\
\hline Cassiope tetragona & 3 & $3-4$ & & & & & $4-5$ & $4-6$ & $5-6$ & $5-6$ \\
\hline Dryas integrifolia & 2 & $3-4$ & $3-4$ & 4 & $3-4$ & $4-5$ & $4-6$ & $5-6$ & $4-6$ & 6 \\
\hline Salix arctica & $3-4$ & 4 & 4 & 4 & 4 & $5-6$ & 5 & 6 & 6 & $5-6$ \\
\hline Papaver radicatum & & $3-4$ & $3-4$ & 4 & 4 & $4-5$ & $4-5$ & & $4-5$ & $4-5$ \\
\hline Saxifraga aizoides & & & & & & & $3-4$ & 4 & & \\
\hline Rhododendron lapponica & & & & & & & $5-6$ & $5-6$ & & \\
\hline Potentilla uniflora/nivea & & & & & & & 4 & $4-5$ & $4-5$ & \\
\hline Silene acaulis & & & & & & & & $4-5$ & $4-5$ & $5-6$ \\
\hline
\end{tabular}


Table 3. The numbers of each species of Lepidoptera collected during the Tundra Northwest 99 expedition. Letters indicate the sites (see Table 1). ${ }^{*}$ indicates that the species was recorded as larva or pupa that subsequently emerged.

\begin{tabular}{|c|c|c|c|c|c|c|c|c|c|c|c|c|}
\hline \multirow[b]{2}{*}{ Family/Species } & \multicolumn{12}{|c|}{ Site } \\
\hline & $A$ & $\mathrm{~B}$ & $\mathrm{C}$ & $\mathrm{D}$ & $E$ & $\mathrm{~F}$ & $\mathrm{G}$ & $\mathrm{H}$ & 1 & $J$ & $\mathrm{~K}$ & $\mathrm{~L}$ \\
\hline \multicolumn{13}{|l|}{ Pieridae } \\
\hline Colias philodice (Godart, 1819) & - & - & - & - & - & - & - & - & - & $5 ?$ & - & - \\
\hline Colias hecla Lefèvbre, 1836 & - & - & - & - & - & - & 1 & - & 54 & - & 13 & - \\
\hline Colias nastes Boisduval, 1834 & - & $1^{*}$ & - & - & - & - & - & - & 13 & - & - & 2 \\
\hline Colias palaeno (Linnaeus, 1761) & - & - & - & - & - & - & $1 ?$ & - & - & - & - & - \\
\hline \multicolumn{13}{|l|}{ Lycaenidae } \\
\hline Lycaena phlaeas (Linnaeus, 1761) & - & - & - & - & - & - & - & - & 2 & - & 1 & - \\
\hline Agriades glandon (de Prunner, 1798) & - & $1^{*}$ & - & - & - & - & - & - & 2 & - & 2 & - \\
\hline \multicolumn{13}{|l|}{ Nymphalidae } \\
\hline Boloria napaea (Hoffmansegg, 1804) & - & - & - & - & - & - & - & 2 & - & - & - & - \\
\hline Boloria frigga (Thunberg, 1791) & - & - & 1 & - & - & $1^{*}$ & - & - & - & - & - & 1 \\
\hline Boloria improba (Butler, 1877) & - & - & - & - & - & - & - & - & 23 & - & - & - \\
\hline Boloria polaris (Boisduval, 1828) & - & 2 & 33 & - & - & 26 & 4 & - & 14 & - & - & 1 \\
\hline Boloria freija (Thunberg, 1791) & - & 2 & - & - & - & 4 & - & - & - & - & - & - \\
\hline Boloria chariclea (Schneider, 1794) & - & - & - & - & - & - & 1 & - & 41 & 1 & 20 & - \\
\hline Erebia fasciata Butler, 1868 & - & - & - & - & - & - & 2 & - & 7 & - & - & - \\
\hline Oeneis bore (Schneider, 1792) & - & - & - & - & - & - & 9 & - & - & - & - & - \\
\hline Oeneis melissa (Fabricius, 1775) & - & - & - & - & - & - & 11 & - & 1 & - & - & - \\
\hline Oeneis polixenes (Fabricius, 1775) & - & - & - & - & - & - & 3 & - & 10 & - & - & - \\
\hline \multicolumn{13}{|l|}{ Geometridae } \\
\hline Psychophora sabini Kirby & - & - & - & 1 & 2 & 1 & - & - & - & - & 4 & - \\
\hline Entephria punctipes (Curtis, 1835) & - & - & - & - & - & - & - & - & 4 & - & 18 & - \\
\hline Aspitates orciferarius (Wilkinson, 1863) & - & - & - & - & - & - & - & 2 & - & - & - & - \\
\hline \multicolumn{13}{|l|}{ Arctiidae } \\
\hline Grammia quenseli (Pay & - & - & - & - & - & - & - & - & 4 & - & - & - \\
\hline Pararctia lapponica (Thunberg, 1791) & - & - & - & - & - & 1 & - & - & - & - & - & - \\
\hline \multicolumn{13}{|l|}{ Family Lymantriidae } \\
\hline Gynaephora rossi Curtis, 1835 & - & 4 & 16 & - & - & 50 & - & $1^{*}$ & 1 & - & - & - \\
\hline Gynaephora groenlandica (Wöcke, 1874) & - & - & 3 & - & 1 & 7 & - & - & 19 & - & 2 & - \\
\hline \multicolumn{13}{|l|}{ Noctuidae } \\
\hline Xestia quieta (Hüb & - & - & - & - & - & - & - & - & 1 & - & - & - \\
\hline Xestia thula Lafontaine \& Kononenko, 1983 & - & - & - & - & - & - & - & - & 1 & - & - & - \\
\hline Polia richardsonii (Curtis, 1834) & - & - & - & - & - & - & - & - & 1 & - & - & - \\
\hline Sympistis zetterstedtii (Staudinger, 1857) & - & - & - & - & - & - & - & - & 1 & - & 1 & - \\
\hline Lasionycta leucocycla (Staudinger, 1857) & - & - & - & - & - & - & - & - & 14 & - & - & - \\
\hline \multicolumn{13}{|l|}{ Pterophoridae } \\
\hline Stenoptilodes petra & - & - & - & - & - & - & - & - & 6 & - & - & - \\
\hline Stenoptilia mengeli (Fernald, 1898) & - & - & - & - & - & - & - & - & 2 & - & - & - \\
\hline \multicolumn{13}{|l|}{ Pyralidae } \\
\hline Loxostege ephippialis (Zetterstedt, 1839) & - & - & - & - & - & - & - & - & 1 & - & - & - \\
\hline \multicolumn{13}{|l|}{ Tortricidae } \\
\hline Olethreutes mengelana (Fernald, 1894) & - & - & - & - & - & - & - & - & - & - & 1 & - \\
\hline Olethreutes inquietana (Walker, 1863) & - & - & - & - & - & - & - & - & 1 & - & 3 & - \\
\hline Aphelia septentrionalis Obroztsov, 1959 & - & - & - & - & - & - & - & - & 2 & - & - & - \\
\hline
\end{tabular}


were attracted by females of both species (Rydell et al. 2000). Two Gynaephora larvae found on Cornwallis Island (site D), and many empty or parasitized cocoons; four from Victoria Island (site G), several dozens from Somerset Island (site C) and about three hundred from south Banks Island (site I). These specimens also remained unidentified to species.

\section{Discussion}

The diversity of the Arctic Lepidoptera fauna decreases rapidly from south to north (Downes 1964, 1966). At the same time, the holarctic range of many species implies that longitude is not a major factor determining the faunal composition. Latitude is more important, but still not the only factor affecting faunal diversity; climatic factors such as cloud cover and wind, as well as altitude and vegetation must also be taken into account. A floristic zonation scheme for the Arctic (Young 1971) appears to present a useful conceptual framework on which to build an improved picture of the distribution of at least Arctic butterflies. Young (1971) defines the Arctic as the regions north of the tree line, and divides it into four zones based purely on floristic grounds. In particular, one climatic parameter - the number of degreemonths above $0{ }^{\circ} \mathrm{C}$ - proved to be well correlated with these zones. Fig. 1 shows the approximate location of Young's zones for the region covering the collection sites for this study.

Roughly, Zone 1 has no butterflies, while Zone 2 has six species: Colias hecla, C. nastes, Lycaena phleas, Agriades glandon, Boloria chariclea and B. polaris (Philip 1983, Layberry et al. 1998). Six more species, basically part of the Zone 3 fauna, also extend into the southern part of Zone 2: Colias tyche, Boloria frigga, $B$. improba, Erebia rossi, Oeneis melissa and $O$. polixenes. Zone 3 has all the above species plus four more: Colias palaeno, Boloria napaea, $B$. freija and Erebia fasciata. Zone 3 in North America has a homogenous butterfly fauna along a 4000-km east-west band from the Arctic coastal plain in Alaska to Baffin Island (Philip 1983). Zone 4 in western North America has over 40 species of butterflies, a few of which may at times stray into lower Zone 3; e.g. Boloria natazhati in the Kuujjua River valley, Victoria Island (Troubridge \& Wood 1990). In Zone 4 longitudinal effects begin to appear, and the eastern North American fauna is somewhat smaller than in the west.

In the Aleutian Islands and the Alaska Peninsula, and in Greenland, the Zone 4 species numbers are much lower, presumably due to cloudy and windy summers in the former case and geographic isolation in the latter. The known butterfly fauna of Greenland is limited to five species: Colias hecla, C. nastes, Lycaena phleas, Agriades glandon and Boloria chariclea (Wolff 1964). All of these are found at Lake Hazen, Ellesmere Island, indicating the source of the Greenland fauna (Downes 1966). There is one sight record of an Oeneis sp. in west Greenland (R. Holland, pers. comm.), which, if confirmed, would be the first indication that a butterfly species has succeeded in crossing Davis Strait.

Our collecting efforts generally corroborated the hypothesis outlined above. According to the range maps in Layberry et al. (1998), the butterfly fauna of the eastern part of the Melville Peninsula (Zone 3) and Somerset Island (Zone 2) appear to have been completely unknown, and this seems to apply to King William Island (Zone 3) as well. Hence, our records of Boloria polaris from these three sites fill gaps in the distribution map for the species. This also applies to our records of Colias nastes, Agriades glandon and Boloria freija from Melville Peninsula, and to that of Boloria frigga from King William Island. Our record of B. frigg a from Somerset Island represents a northern range extension for this species (Layberry $e t$ al. 1998).

The only Lepidoptera previously identified to species from Bathurst Island (Zones 1 and 2) was the geometrid Psychophora sabini (Danks \& Byers 1972), although there are sight records of "hairy larvae", presumably a Gynaephora species, from Polar Bear Pass on the central part of the island (Danks 1980). We confirmed that the lymantriid Gynaephora groenlandica occurs on the southern part of Bathurst Island (Zone 2). Gynaephora groenlandica has a wide distribution across the Canadian arctic archipleago and Greenland, but particularly in Canada the sites where it has previously been collected are located far apart (see Kukal \& Kevan 1977, Danks 1981). This is also true for its congeneric G. rossi. This species 
occurs sympatrically with $G$. groenlandica in arctic Canada, but it is absent from Greenland (Danks 1981). Our records of G. groenlandica at Somerset, King William and southern Banks Islands and those of G. rossi at Somerset Island, Banks Islands and Pearce Point fill some gaps in the distribution records of these two species.

The Arctiid Grammia quenseli, which we recorded on southern Banks Island, is widespread in low arctic areas of Canada and Alaska (Danks 1981). It also occurs in alpine areas further south (e.g. southern Quebec and New England; Ferguson 1985), but published records are few. Our records from southern Banks Island and two earlier ones, cited in Ferguson et al. (2000), from Sachs Harbour (Banks Island) and Kuujjua River Valley (western Victoria Island), respectively, show that $G$. quenseli also occurs in the southern part of the arctic archipelago. The other Arctiid Pararctia lapponica is widespread in the Nearctic although it has previously not been recorded from King William Island, where we found it. It was previously known from the neighbouring Boothia Peninsula and eastern Victoria Island (Sotavalta 1965). Our record of the pyralid Loxoxtege ephippialis, a Holarctic species common in the low arctic, from Banks Island probably represents a range extension towards the north of this species.

It should be noted that we considered all green Colias specimens as belonging to $C$. nastes (Boisduval) and none to $C$. tyche (deBöber) subspecies thula (according to the taxonomy used in Layberry et al. 1998). This conclusion is based on KWP's judgment, following comparisons with nastes and thula specimens in the Alaska Lepidoptera Survey. Reliable separation of single specimens of the two forms from Arctic Canada is difficult, and how it should be done is apparently not fully worked out (K. Mikkola pers. comm.).

Acknowledgements. We acknowledge many expedition colleagues, including Lucas Amagoalik, Joakim Hjältén and Jens Molin for help with collecting specimens, and Håkan Elmquist, Erkki M. Laasonen and Kauri Mikkola for help and advice concerning species determination. We also thank Martin Bölter for providing temperature readings and information on soil and humidity, Bente Eriksen and Ulf Molau for plant-species lists and general information on the flora, and Esther Lévesque for help with compilation of the plant phenology table. We also acknowledge the ship and helicopter crews for their great efforts and professionalism throughout the expedition and the communities in Nunavut and North West Territories for permission to use their land and collect specimens. The scientific work was financed by the Swedish Natural Science Research Council (to JR) and the University of Joensuu and the Finnish Academy (to HR). The expedition was organised and financed by the Swedish Polar Research Secretariat in cooperation with the Canadian Coast Guard.

\section{References}

Bliss, L. C. (ed.) 1977: Truelove Lowland, Devon Island, Canada: a high Arctic ecosystem. - University of Alberta Press, Edmonton.

Danks, H. V. 1980: Arthropods of Polar Bear Pass, Bathurst Island, Arctic Canada. - Syllogeus (National Museum of Natural Sciences, Ottawa) 25: 1-69.

Danks, H. V. 1981: Arctic arthropods. A review of systematics and ecology with particular reference to the North American fauna. - Entomological Society of Canada, Ottawa.

Danks, H. V. \& Byers, J. R. 1972: Insects and arachnids of Bathurst Island, Canadian arctic archipelago. - Canadian Entomologist 104: 81-88.

Downes, J. A. 1964: Arctic insects and their environment. - Canadian Entomologist 96: 279-307.

Downes, J. A. 1966: The Lepidoptera of Greenland; some geographic considerations. - Canadian Entomologist 98: 1135-1144.

Ferguson, D. C. 1985: Contributions toward reclassification of the world genera of the tribe Arctiini, Part 1. Introduction and a revision of the Neoarctia-Grammia group (Lepidoptera: Arctiidae; arctiinae). — Entomography 3: 181-275.

Ferguson, D. C., Opler, P. A., Smith, M. J. \& Donahue, J. P. 2000: Distribution of Arctiidae of western North America, part 1. Text, systematic list, bibliography, and maps. - Contributions to C. P. Gillette Museum of Arthropod Biodiversity, no. 3.

Grönlund, E. (ed.). 2000: Polarforskningssekretariatets årsbok 1999. — Polarforskningssekretariatet, Stockholm.

Kukal, O. \& Kevan, P. G. 1977: The influence of parasitism on the life history of a high-Arctic insect, Gynaephora groenlandica (Wöcke) (Lepidoptera: Lymantriidae). In: Svoboda, J. \& Freedman, B. (eds.), Ecology of a polar oasis: Alexandra Fiord, Ellesmere Island, Canada. Captus University Publications, Toronto, pp. 231-239.

Layberry, R. A., Hall, P. W. \& Lafontaine, J. D. 1998: The Butterflies of Canada. - Toronto University Press, Toronto.

McAlpine, J. F. 1964: Arthropods of the bleakest barren lands: Composition and distribution of the arthropod fauna of the northwestern Queen Elizabeth Islands. Canadian Entomologist 96: 127-129. 
Philip, K. W., 1983: Butterflies of the Western North Slope and Victoria Island, with special reference to Arctic butterfly zonation. - National Geographic Society Research Reports 15: 513-522.

Rydell, J., Roininen, H. \& Philip, K. W. 2000: Persistence of bat defence reactions in high Arctic moths. - Proceedings of the Royal Society of London B 267: 553-557.

Sotavalta, O. 1965: A revision of the genus Hyphoraia Hübner s. lat. (Lepidoptera, Arctiidae). — Annales Entomologici Fennici 31: 159-197.

Svoboda, J. \& Freedman, B. (eds.). 1994: Ecology of a po- lar oasis: Alexandra Fiord, Ellesmere Island, Canada. - Captus University Publications, Toronto.

Troubridge, J. T. \& Wood, D. M. 1990: Biology and taxonomic status of Boloria natazhati (Gibson) (Nymphalidae). — Journal of the Lepidopterists' Society 44: 180-187.

Wolff, N. L. 1964: The Lepidoptera of Greenland. Meddelelser om Grönland 159: 1-74.

Young, S. B. 1971: The vascular flora of St. Lawrence Island with special reference to floristic zonation in the arctic regions. - Contributions to the Gray Herbarium 201: 11-115. 